\title{
APPLICATION OF THE LEAN CONCEPT FOR ANALYSIS AND OPTIMIZATION OF THE AUTOMOBILE FILTER PRODUCTION COMPANY
}

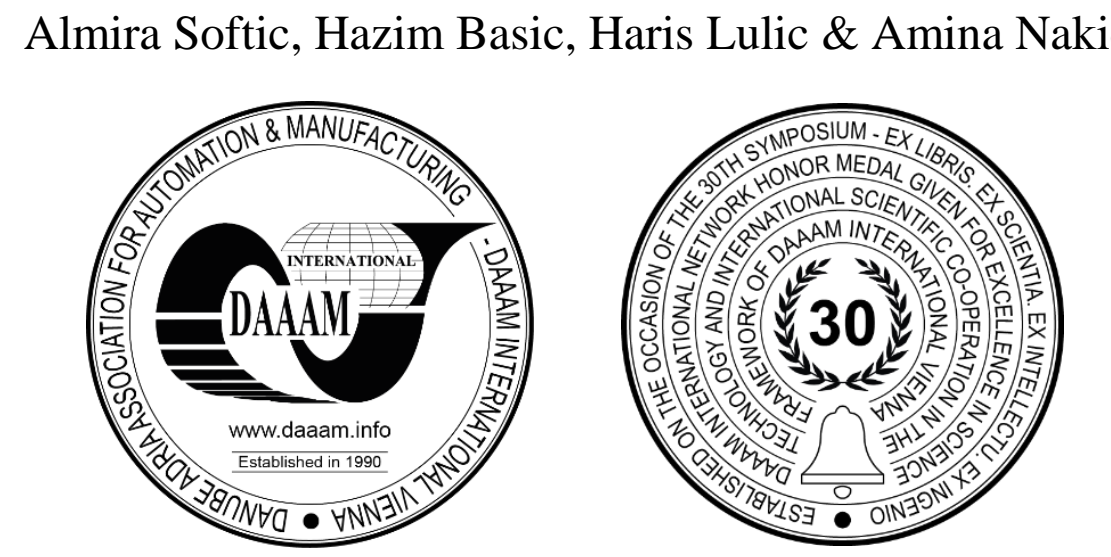

This Publication has to be referred as: Softic, A[1mira]; Basic, H[asim]; Lulic, H[aris] \& Nakic, A[mina] (2020). Application of the Lean Concept for Analysis and Optimization of the Automobile Filter Production Company, Proceedings of the 31st DAAAM International Symposium, pp.0708-0716, B. Katalinic (Ed.), Published by DAAAM International, ISBN 978-3-902734-29-7, ISSN 1726-9679, Vienna, Austria DOI: $10.2507 / 31$ st.daaam.proceedings.098

\begin{abstract}
The increase in customer demands caused issues within a filter production company due to its processes which could not ultimately satisfy new requests. The main hardships faced by the company were: meeting delivery deadlines, manufacturing the increased quantities and lastly, a reasonable final price of the product. This paper demonstrates the utilization of modern Lean methods and quality management tools in a filter production company, as a way to problem solve the demands of customer requests. Lean management was used to optimize and increase production, to minimize or completely eliminate waste in the identified problems of the production area and logistic activities within the company. Lean enabled development of diverse solutions which, when implemented, resulted in material and immaterial savings. With Lean implementation, the company was able to improve on organizational operations such as ergonomics, transportation routes and production flows.
\end{abstract}

Keywords: Lean methods; Quality management tools; Filter production; Waste reduction.

\section{Introduction}

The aim of this study is to demonstrate how a production company may easily adapt to different market conditions in order to remain competitive. To adapt to different market demands, it was necessary to discover problematic areas in production and logistic activities and find their solutions. Problematic areas were determined by the volume of waste/losses and for this purpose, the filter production company utilized lean management as a systematic approach for identifying and eliminating waste in manufacturing processes with continuous improvements in pursuit of perfection. [1] Halts in process, low efficiency, failure of equipment, inventory, poor ergonomics, inefficient machine layouts, long transportation routes, inexistent one-piece flow, bottlenecks, defective products, and inaccessible materials are all of the issues that were experienced in the filter production company after they received new customer demands. In the productional sense, the mentioned issues are considered as waste because they increase costs without adding value to the product. The issues mentioned in the filter production company can be categorized, according to Lean, as the type of waste that occurs most frequently. [2], [3] 
Waste increases existing productional and logistic issues, and negatively results in scrap waste, increases energy consumption costs, and maintains the sales price of the product high which does not promote the filter production company to sufficiently meet the demands of the changing market.

Application of the Lean concept for analysis and optimization of the automobile filter production company within DMAIC phases (Define, Measure, Analyse, Improve, Control), and a standardized method of problem solving are presented within this paper. [4], [5] The quality management tools used within the Lean methods are considered modern tools and do not have much emphasis on statistics, but are solely based on the systematization of verbal data such as graphical, data analysis, problem identification, decision making, modelling, error prevention and lastly, creative tools. [2] It is important to identify issues in a timely manner, determine the appropriate Lean method, select the appropriate quality management tools or in accordance with the selected Lean method, combine multiple quality management tools as well. Lean methods are the ideas while quality management tools are the means that enable the realization of the improvement process. The Toyota company successfully authored and demonstrate the core of the Lean concept. The application of the Toyota production system was used as an example for the filter production company in order to adapt to different market conditions. The Toyota production system or Lean management - how it is referenced today, has evolved out of need when the Japanese automobile industry faced the post-WWII period - when the marketplace demands drastically changed. [6], [7], [8] The most important objective of Toyota system has been to increase production efficiency by consistently and thoroughly eliminating waste. Their system was established on the idea of continuous improvement [9], with the objective of making the vehicles ordered by customers in the quickest and most efficient way, instead of mass production (customer-oriented approach). From the post-WWII era to the present, Toyota, as a company has managed to evolve in the midst of enormous internal and external changes. [10]

\section{The problem defining phase within the filter production process}

The problem defining phase enabled Lean team members to deal with production processes, identify the process framework, recognize actual and desired outputs, and define the problems. The company was not able to satisfy new, higher customer demands in a desirable time frame, due to low production rates on several operations and the high price of the products. During the optimization process, root causes of the mentioned problems will be identified. The Supplier - Input - Process - Output - Customer (SIPOC) diagram, Voice of the Customer (VOC) tool in combination with the Critical to Quality (CTQ) table and the flowchart diagram, are used in the problem defining phase.

\subsection{Problem analysis}

SIPOC diagram is a tool that simplifies variables of the manufacturing process and is used in the beginning phase of the DMAIC in order to identify suppliers, input units, processes that need optimization, output units and customers. [11] Table 1. demonstrates the SIPOC diagram created within the company. Customer demands refer to more reasonable prices of the final products. To satisfy customer requests, it was necessary to reduce the price of the final product by optimization of the filter assembly process.

\begin{tabular}{|c|c|c|c|c|c|}
\hline Supplier & Input & Process & Output & $\begin{array}{l}\text { Customer } \\
\text { requirements }\end{array}$ & Customer \\
\hline $\begin{array}{l}\text { Filter } \\
\text { company }\end{array}$ & $\begin{array}{l}\text { Investments for } \\
\text { improving filter } \\
\text { production processes }\end{array}$ & \multirow{6}{*}{$\begin{array}{l}\text { Optimization of } \\
\text { the filter } \\
\text { production } \\
\text { process }\end{array}$} & $\begin{array}{l}\text { Reduced price of the } \\
\text { final product }\end{array}$ & $\begin{array}{l}\text { Acceptable price of the } \\
\text { final product }\end{array}$ & $\begin{array}{l}\text { Not Presented } \\
\text { due to Privacy }\end{array}$ \\
\hline $\begin{array}{l}\text { External } \\
\text { Suppliers }\end{array}$ & $\begin{array}{l}\text { Machines and } \\
\text { devices }\end{array}$ & & $\begin{array}{l}\text { Quality and quantity } \\
\text { of the final product }\end{array}$ & $\begin{array}{l}\text { Product within } \\
\text { specification limits }\end{array}$ & $\begin{array}{l}\text { Not Presented } \\
\text { due to Privacy }\end{array}$ \\
\hline \multirow[t]{4}{*}{ Warehouse } & $\begin{array}{l}\text { Semi-finished } \\
\text { products }\end{array}$ & & $\begin{array}{l}\text { Higher production } \\
\text { rates on the crimping } \\
\text { operation }\end{array}$ & $\begin{array}{l}\text { Optimization of the filter } \\
\text { production processes } \\
\text { (crimping and } \\
\text { permeability testing) }\end{array}$ & $\begin{array}{l}\text { General } \\
\text { Manager }\end{array}$ \\
\hline & & & $\begin{array}{l}\text { Higher production } \\
\text { rates on the } \\
\text { permeability testing } \\
\text { operation }\end{array}$ & $\begin{array}{l}\text { Optimization of the filter } \\
\text { production processes } \\
\text { (crimping and } \\
\text { permeability testing) }\end{array}$ & $\begin{array}{l}\text { General } \\
\text { Manager }\end{array}$ \\
\hline & & & Quantity and due dates & $\begin{array}{l}\text { Quality of the final } \\
\text { product and timely } \\
\text { production }\end{array}$ & $\begin{array}{l}\text { Delivery } \\
\text { Warehouse }\end{array}$ \\
\hline & & & $\begin{array}{l}\text { Internal filter } \\
\text { production }\end{array}$ & External filter production & $\begin{array}{l}\text { Global } \\
\text { Management }\end{array}$ \\
\hline
\end{tabular}

Table 1. SIPOC tool for problem analysis with the oil filter production [12] 


\subsection{The customer requests identification}

VOC is tool based on the identification of the customer demands (listed and unlisted), attitudes toward the products, and services provided. The CTQ tool defines critical measurable products or process characteristics with standards and specification limits in order to satisfy customer demands. Therefore, the CTQ must be interpreted from the qualitative aspect of the customer statements into effective, quantitative business specifications. [13]

The VOC tool demonstrates that the customer requested a lower price of the final product. With utilization of the CTQ Tool, it was concluded that the company should reduce the actual price of the product by 15 percent in order to satisfy the customer demands. Therefore, the requirements to meet timely deliveries and compliance with product specifications, these can be achieved by monitoring the timing of orders and deliveries and by increasing the rate of production and ensuring the best quality.

\begin{tabular}{|l|l|l|l|}
\hline \multicolumn{1}{|c|}{ VOC } & \multicolumn{1}{|c|}{ Detailed statement } & \multicolumn{1}{c|}{ CTQ } & \multicolumn{1}{c|}{ Comment } \\
\hline $\begin{array}{l}\text { Reducing cost of the } \\
\text { filter production }\end{array}$ & $\begin{array}{l}\text { Optimization of the crimping } \\
\text { and permeability testing } \\
\text { processes }\end{array}$ & Reduce the price by 15\% & $\begin{array}{l}\text { Whole project }-15 \% \\
\text { Project }-15 \%\end{array}$ \\
\hline $\begin{array}{l}\text { Higher rate of the } \\
\text { crimping operation }\end{array}$ & Project & $\begin{array}{l}100 \% \text { higher rate by comparison } \\
\text { with actual situation }\end{array}$ & $\begin{array}{l}\text { Current crimping rate } 600 \\
\text { pieces per shift }\end{array}$ \\
\hline $\begin{array}{l}\text { Higher rate of the } \\
\text { permeability testing } \\
\text { operation }\end{array}$ & Project & $\begin{array}{l}166,67 \% \text { higher rate by } \\
\text { comparison with actual situation }\end{array}$ & $\begin{array}{l}\text { Current permeability testing } \\
\text { rate } 450 \text { pieces per shift }\end{array}$ \\
\hline $\begin{array}{l}\text { Timely delivery } \\
\text { Project }\end{array}$ & $\begin{array}{l}\text { Managing orders and } \\
\text { deliveries }\end{array}$ & $\begin{array}{l}\text { Qualitative and Quantitative } \\
\text { reclamations 0ppm }\end{array}$ & \\
\hline $\begin{array}{l}\text { Product within } \\
\text { specification limits }\end{array}$ & Quality & & \\
\hline
\end{tabular}

Table 2. Combination of VOC and CTQ tools [12]

\subsection{Sequential order of the filter production process}

The Flowchart diagram was incorporated in the defining problems phase of the DMAIC, with the aim of demonstrating existing processes by inputting activities in a sequential order of the filter production process. The Flowchart diagram show a graphical symbol for activities, decisions, boundary points, attachment points, process lines, documents, notes and file descriptions.

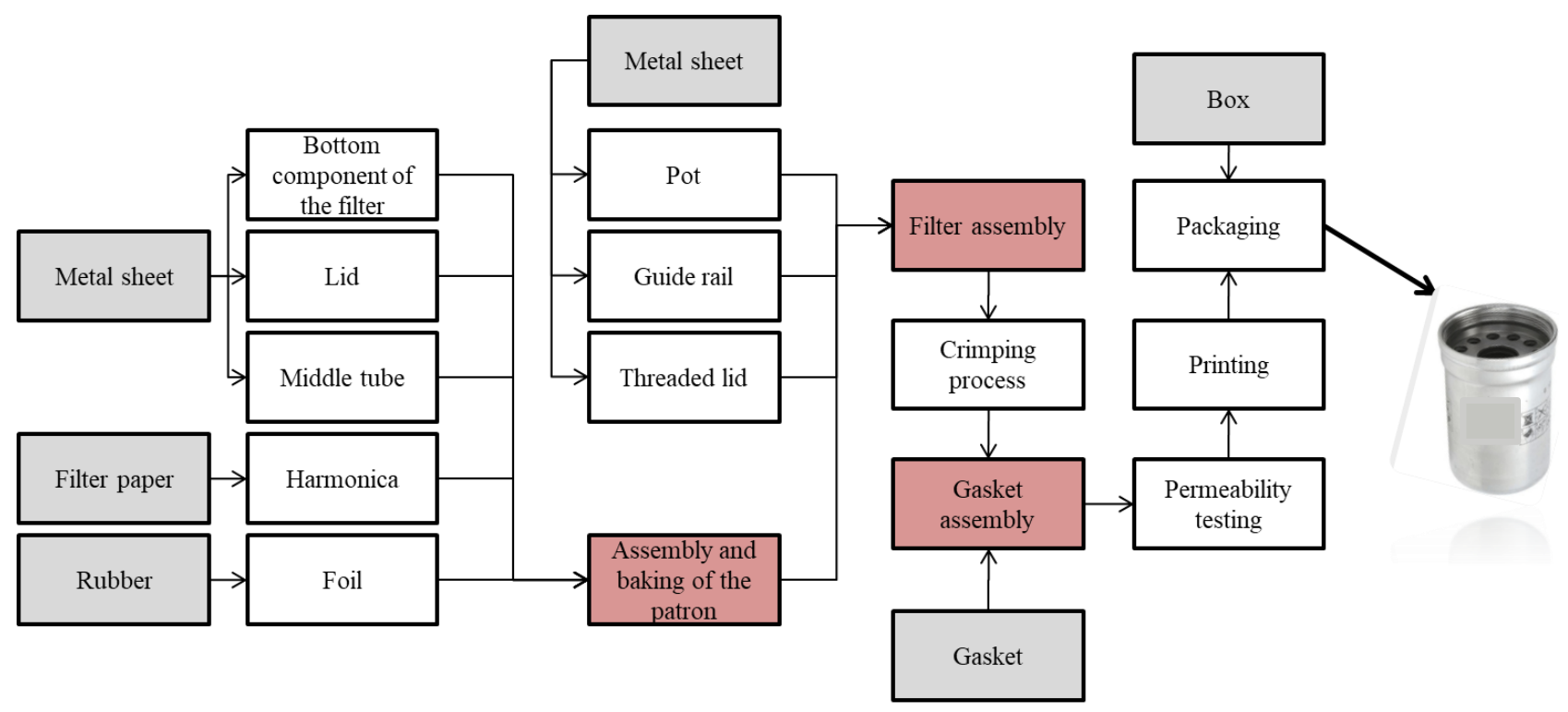

Fig. 1. Flowchart diagram of filter production [12] 
Flowchart diagram represents production process, data and flow of materials, used for examinations and as improvements basis. [14] The diagram in figure 1. demonstrates steps of oil filter manufacturing process: filter component production, assembly, crimping process, gasket assembly, filter permeability testing, printing and packing.

\section{The phase of measuring performance process steps}

The Data collection plan contains the following: controlled processes, controlled data, measurements, and the locations of measuring activities. Within the measuring phase, value stream mapping was created with the purpose of tracking the following times: lead time, cycle time, takt time, Value Added Time (VAT), Non Value Added Time (NVAT) and machine time and it is possible to acquire an illustration of the process steps.

Value stream mapping (VSM) considers all activities, from the start of the order to the delivery of the final product. During the VSM, the value adding activities were recorded, as well as the support activities and waste (ex. tool exchange, halts etc.). [1], [15] The VSM created within the company is shown in figure 2.

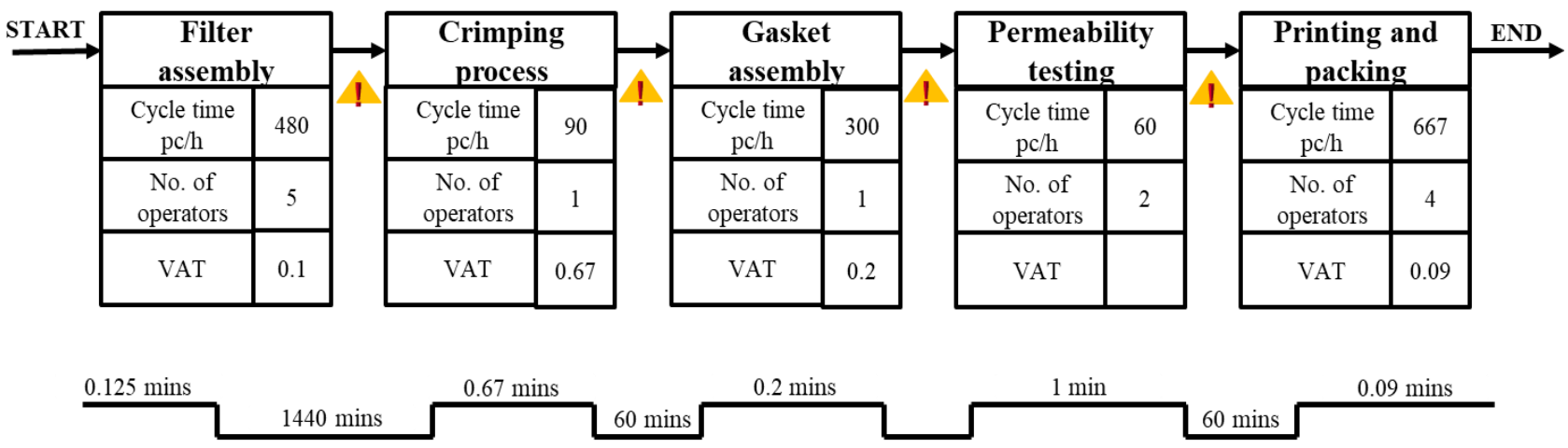

Fig. 2. Value stream mapping [12]

Problems that need to be solved are identified by a prolonged duration of time needing to process one part on the individual operations of the filter manufacturing process and also by the low percentage of activities that add value to the product (VAT).

It is possible to identify bottlenecks by incorporating chart visualizations of the cycle times of operations in the filter production process (measure in the mapping activities). The bottlenecks have the longest lead times, hence, the least amount of parts produced per hour. In figure 3., bottlenecks are represented in red.

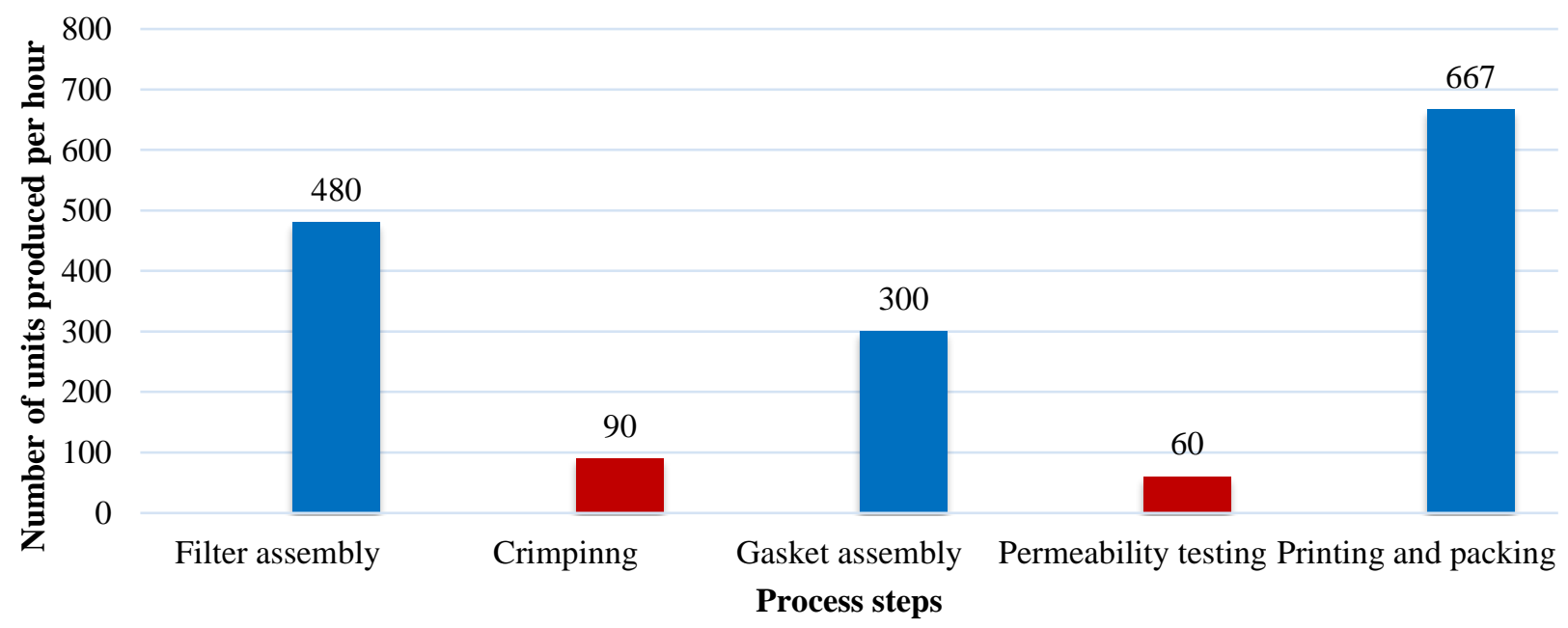

Fig. 3. Number of units produced per hour, per process steps [12]

Crimping and permeability testing processes were the bottlenecks and obstacles in satisfying the demands of the customers. Problems can be triggered by unsatisfactory machine layouts, poor workplace ergonomics, equipment failure, downtime, and delays. 


\subsection{Analysis of the machine layout}

Layouts of the filter assembly line, crimping operation of the filter metal components and permeability testing, printing, and packing operations are shown in Figure 4. Machine layouts on the other operations of the filter production process are satisfactory.
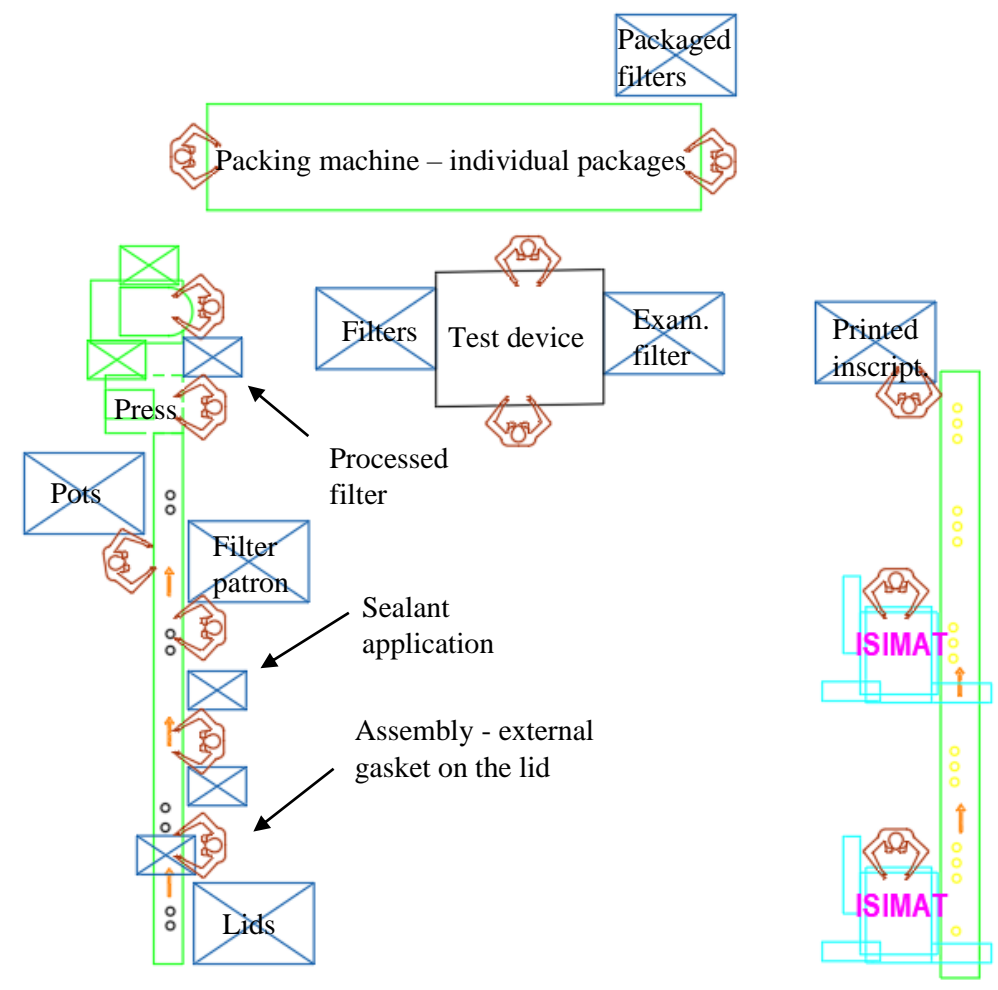

Fig. 4. The actual layout of assembly line and the machines on the other operations [12]

Figure 4., shows that machines on the assembly line are too distant, workplaces are isolated, the filter assembly operation parts are not easily accessible and employee scheduling is not satisfactory and such a layout, resulted in long transportation routes, unnecessary employees movements and production stagnation. The halts in the crimping process were caused by the busyness of the machine due to another order in the progress. After the machine starts crimping the pot and lid for the oil filter, the first 6 crimped pieces are always required to be tested in the laboratory, which requires additional time, since the machine is at standstill point until the test results are ready. Delays also occur in the installation process of the gasket due to waiting for the adequate amount of the crimped parts and long transport routes. Gasket installation is completed at a slower pace due to the absence of the One-Piece Production Flow.

The Spaghetti diagram is used for analysis of any process which includes movement of employees, material flow or flow of the goods, with the purpose of understanding the order of tasks to be completed, the condition of the actual process and finding possibilities for improvement. [16]

\subsection{Identification of the priority problems}

It is necessary to rank the causes of the problems that are defined by the utilization of the Ishikawa diagram, according to the importance to the customer (as shown in Table 3), in order to identify the causes of the problems which are more important to resolve in comparison to others. Ishikawa diagram is a method for a detailed analysis of the relations between a particular effect (problem or consequence) and the infuential magnitudes of potencial causes that generate the occurence of the given effect. According to Ishikawa diagram, the categorization of the causes for the high filter production costs and low rate of crimping and permeability testing operations was performed within the next groups that represent the main causes: Machinery, Manpower, Method, Material, Maintenance and Milieu.

Customer ratings are shown in column A, C and E in Table 3. The problems with the high costs of the final product and slow pace on crimping and permeability testing operations were ranked on a scale of 1-10. Columns B, D and F represent the product of the rate of the problem importance and the rate of the importance of each of the causes, and they represent the scale on the radar diagram. Five priority potential causes of problems are marked in red. 


\begin{tabular}{|c|c|c|c|c|c|c|c|c|c|}
\hline & \multicolumn{2}{|c|}{ Customer ratings of importance } & \multicolumn{2}{|c|}{5} & \multicolumn{2}{|c|}{4} & \multicolumn{2}{|c|}{4} & \\
\hline & \multicolumn{2}{|c|}{ Customer requirements } & \multicolumn{2}{|c|}{$\begin{array}{l}\text { Reducing filter } \\
\text { production costs }\end{array}$} & \multicolumn{2}{|c|}{$\begin{array}{l}\text { Higher rate on } \\
\text { crimping } \\
\text { operation }\end{array}$} & \multicolumn{2}{|c|}{$\begin{array}{c}\text { Higher } \\
\text { permeability } \\
\text { testing rate }\end{array}$} & \\
\hline & Process Input & Columns & $\mathbf{A}$ & B & $\mathbf{C}$ & $\mathbf{D}$ & $\mathbf{E}$ & $\mathbf{F}$ & Total \\
\hline 1 & \multicolumn{2}{|c|}{ Machine preparation time } & 9 & 45 & 6 & 24 & 3 & 12 & 81 \\
\hline 2 & \multicolumn{2}{|c|}{ Viscosity of the sealing glue } & 7 & 35 & 1 & 4 & 1 & 4 & 43 \\
\hline 3 & \multicolumn{2}{|c|}{ Questionable quality of metal sheet used for pot man. } & 8 & 40 & 4 & 16 & 3 & 12 & 68 \\
\hline 4 & \multicolumn{2}{|c|}{ Inadequate conveyor on assembly line } & 9 & 45 & 1 & 4 & 1 & 4 & 53 \\
\hline 5 & \multicolumn{2}{|c|}{ Employees age and ergonomics of workplace } & 7 & 35 & 8 & 32 & 7 & 28 & 95 \\
\hline 6 & \multicolumn{2}{|c|}{ Environment temperature } & 4 & 20 & 3 & 12 & 1 & 4 & 36 \\
\hline 7 & \multicolumn{2}{|c|}{ Age of equipment } & 7 & 35 & 6 & 24 & 7 & 28 & 87 \\
\hline 8 & \multicolumn{2}{|c|}{ Position of production line in the plant } & 7 & 35 & 5 & 20 & 4 & 16 & 71 \\
\hline 9 & \multicolumn{2}{|c|}{ Inadequate production line layout } & 10 & 50 & 10 & 40 & 10 & 40 & 130 \\
\hline 10 & \multicolumn{2}{|l|}{ No backup options } & 4 & 20 & 3 & 12 & 3 & 12 & 44 \\
\hline 11 & \multicolumn{2}{|l|}{ Motivation } & 5 & 25 & 4 & 16 & 4 & 16 & 57 \\
\hline 12 & \multicolumn{2}{|l|}{ Crimping machine } & 10 & 50 & 10 & 40 & 2 & 8 & 98 \\
\hline 13 & \multicolumn{2}{|c|}{ Manual testing and packing } & 10 & $\mathbf{5 0}$ & 2 & 8 & 10 & 40 & 98 \\
\hline 14 & \multicolumn{2}{|c|}{ Transport manipulation } & 5 & 25 & 8 & 32 & 6 & 24 & 81 \\
\hline 15 & \multicolumn{2}{|c|}{ Poor machine maintenance } & 4 & 20 & 5 & 20 & 3 & 12 & 52 \\
\hline 16 & \multicolumn{2}{|c|}{ Poor quality of gasket material } & 7 & 35 & 2 & 8 & 4 & 16 & 59 \\
\hline 17 & \multicolumn{2}{|l|}{ Process control } & 7 & 35 & 3 & 12 & 2 & 8 & 55 \\
\hline 18 & \multicolumn{2}{|c|}{ Individual productivity of workstations } & 7 & 35 & 3 & 12 & 2 & 8 & 55 \\
\hline 19 & \multicolumn{2}{|l|}{ Errors in process } & 7 & 35 & 4 & 16 & 3 & 12 & 63 \\
\hline 20 & \multicolumn{2}{|c|}{ Long duration of delivery time for raw materials } & 7 & 35 & 5 & 20 & 4 & 16 & 71 \\
\hline 21 & \multicolumn{2}{|c|}{ Long transportation routes } & 8 & 40 & 4 & 16 & 4 & 16 & 72 \\
\hline & & & & 745 & & 388 & & 336 & \\
\hline
\end{tabular}

Table 3. Ranking the problems and their potencial causes [12]

Figure 5. shows a graphical representation of the table in the form of a radar diagram.

Machine preparation time

Long transportation routes $150 \quad$ Viscosity of the sealing glue

Long duration of delivery... Questionable quality of...

Errors in process

Individual productivity of...

Process control

Poor quality of gasket...

Poor machine maintenance

Transport manipulation

Manual testing and packing Crimping machine
100

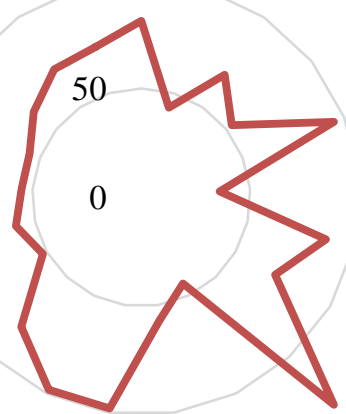

Motivation
Inadequate conveyor on...

Employees age and...

Environment temperature

Age of equipment

Position of production line... Inadequate production line...

No backup options

Fig. 5. Radar diagram [12] 
The broken lines on the radar diagram demonstrate which causes need to be resolved based on priority. According to the radar diagram, the highest priority is to change the layout of the filter assembly line. The other priority items are in the following order: buy a new machine for crimping and permeability testing operations (with automatic drying) and shortening the preparation times of the machines.

\section{The improvement phase}

It is necessary to evaluate ideas that orient with eliminating the main causes of problems, determined by analysis, in the im rovement phase. The solutions may be resources to manage projects, but also, other tools which can be used for planning/managing quality as can be seen in Table 4. [17]

\begin{tabular}{|c|l|l|}
\hline No. of idea & \multicolumn{1}{|c|}{ Idea } & \multicolumn{1}{|c|}{ Note } \\
\hline 1 & Purchasing the permeability testing device & Assembly \\
\hline 2 & Purchasing the machine for crimping operation & Crimping \\
\hline 3 & Change of layout on filter assembly line & \\
\hline 4 & Abolishing the first operation - external service & Packing \\
\hline 5 & Change of employee schedule on crimping operation & Higher production rate \\
\hline 6 & Change of work tasks on filter assembly line & Abolishing the operator \\
\hline 7 & Change of process steps sequence & \\
\hline 8 & Location change of the filter assembly line & \\
\hline 9 & New supplier for the lid & Reducing the costs \\
\hline 10 & New press for the pot production & \\
\hline
\end{tabular}

Table 4. Ideas for solving the root causes of the problems with oil filter production [8]

It is necessary to consider potential risks, during or after the implementation of ideas listed in Table 4, the probability of their occurrence, the magnitude of the risk impact on the process and net profit and countermeasures that need to be taken to neutralize the risk impacts. The potential risks and magnitude of their impacts on the process are shown in Table 5 .

\begin{tabular}{|l|c|c|c|l|}
\hline \multicolumn{1}{|c|}{ Potencial Risks } & $\begin{array}{c}\text { Impact on } \\
\text { the process }\end{array}$ & $\begin{array}{c}\text { Impact on the } \\
\text { neto benefit }\end{array}$ & $\begin{array}{c}\text { Possibility of } \\
\text { the occurence }\end{array}$ & \multicolumn{1}{|c|}{ Preventional acting } \\
\hline Equipment quality & $\mathrm{H}$ & $\mathrm{H}$ & $\mathrm{G}$ & $\begin{array}{l}\text { Clear technical request and constant } \\
\text { communication with the manufacturer }\end{array}$ \\
\hline $\begin{array}{l}\text { Maintenance of the } \\
\text { equipment }\end{array}$ & $\mathrm{H}$ & $\mathrm{H}$ & $\mathrm{M}$ & Total productive maintenance \\
\hline $\begin{array}{l}\text { Training and } \\
\text { experience of the }\end{array}$ & $\mathrm{M}$ & $\mathrm{M}$ & $\mathrm{G}$ & $\begin{array}{l}\text { Educations, audits, control of the } \\
\text { qualification matrics }\end{array}$ \\
\hline $\begin{array}{l}\text { Quality of raw } \\
\text { materials }\end{array}$ & $\mathrm{H}$ & $\mathrm{H}$ & $\mathrm{M}$ & $\begin{array}{l}\text { Contact with the Suppliers and product } \\
\text { audits }\end{array}$ \\
\hline Suppliers & $\mathrm{H}$ & $\mathrm{H}$ & $\mathrm{M}$ & Double source of supplying \\
\hline \multicolumn{5}{|r|}{$\mathrm{H}=$ High M=Medium G=Small } \\
\hline
\end{tabular}

Table 5. Potencial risks [12]

Process optimization and increase in production volumes can be achieved by minimizing or eliminating waste in production and logistic activities with the application of the Lean concept. The quality and maintenance of equipment along with starting raw materials and the reliability of the suppliers have the greatest impact on the process and net benefit. Preventive actions ensure reduction occurences of the defined risks.

Before the attempt to implement the phase with the optimal solution, it was necessery to analyze the possibilities of implementation in regards to the financial aspect.

\subsection{Implementation of the improved solutions}

After reviewal of the economic aspects and reasons for application of the ides, the team in charge approached the implementation of the optimal solutions. The improvement activities were to change the filter assembly line layout, as shown in Figure 6. The new layout of the filter assembly line enables performing the crimping process and the permeability testing process on the assembly line. 


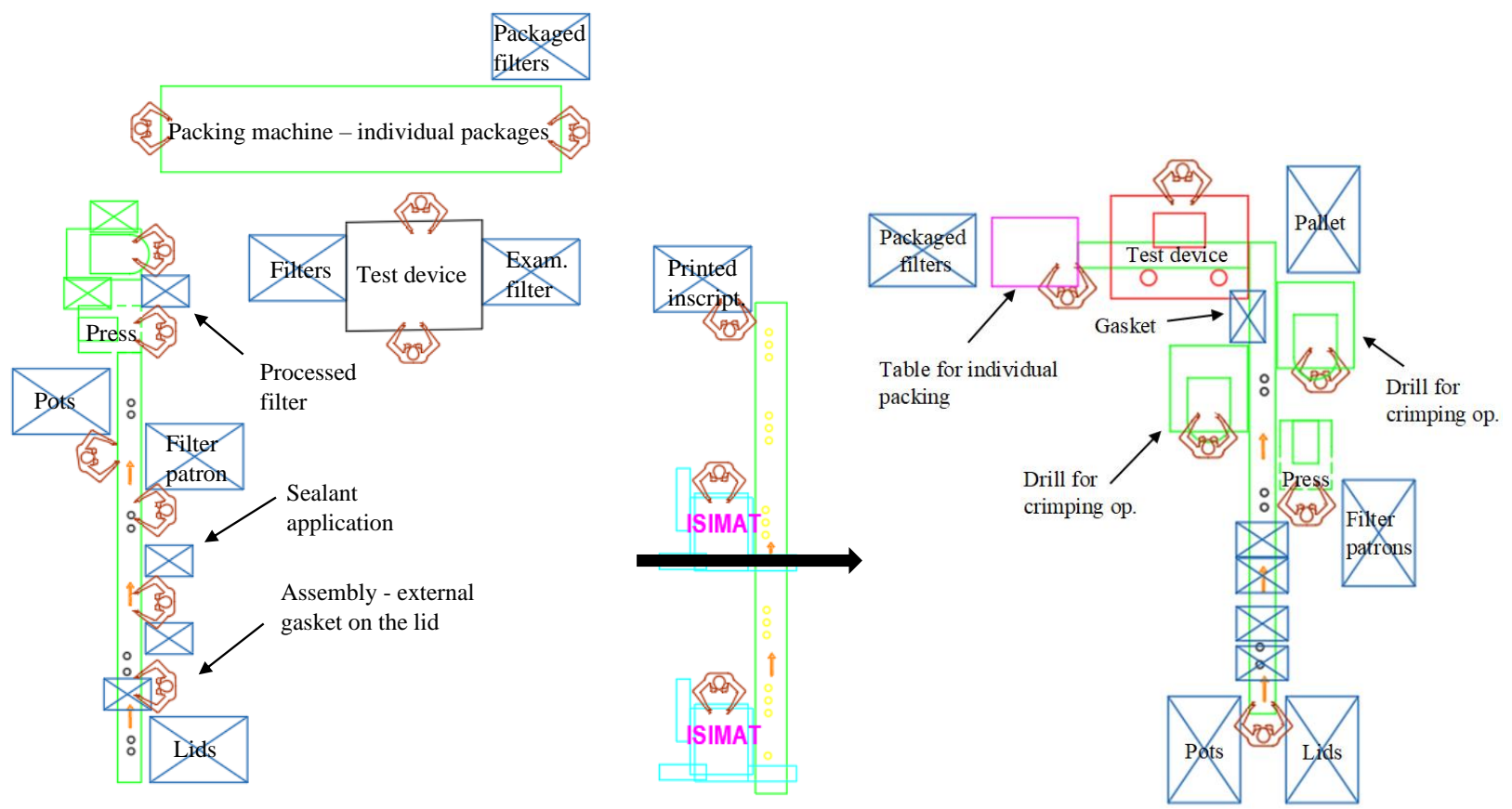

Fig. 6. New layout of the assembly line [12]

Aside from the machine layout, the position of the assembly line was rearranged, tasks were redistributed, the number of employee operators were reduced and their positions during operation were optimized and the process steps were changed (gasket assembly, crimping process, permeability testing process, printing and packaging process). Finally, the new machine layout contributes to the implementation of the One-piece flow system instead of mass production.

\section{Conclusion}

In conclusion, this research shows that the filter production company was successfully able to meet the demands of the changing market by applying the Lean concepts. The filter production company reduced the cost of the final product by $15 \%$, increased production rates on low pace operations up to $167 \%$, and manufactured products within qualitative and quantitative specification limits (managing orders and deliveries in a timely fashion with no reclamations). By the utilization of Lean, the company eliminated transportation waste by improving machine layouts and workplace ergonomics. Bottlenecks and halts in process were resolved by purchasing new equipment and by changing the sequence of operations. The percentage of process errors and defective products were reduced by providing employees with adequate training and assigning them to the same workplace positions. All of the accomplishments mentioned were due to appropriate identification of waste/losses and responding to the identification by reduction and/or elimination of waste. The application and outcome of Lean concepts in a company should always be documented for future improvements. The purpose of documenting the changes is to trend the improvements. The goal of documentation is to also establish a standardized sequence of operation and a standardized way of performing works tasks so that accurate results from the data can be depicted and monitored. Therefore, datasets from previous performances may be compared so that, in turn, improvements may be brought forward again in the future.

Not one process can perfect and there is opportunity for improvement. In essence, this project is truly never completed since improvement will occur continuously into the future. Implementing Lean activities does not solve all problems immediately, but the problem-solving process is a continuous step by step process. Lean activities do not only solve existing problems, but it is possible with Lean to prevent their occurrences and possible reoccurrences. The application of the Lean methods can hardly result in failure, since Lean is a philosophy of continuous small improvements and does not require a large sum of investments along the way. Like all philosophies in business, the Lean approach has its advantages and disadvantages. The advantages are the reduction of costs in the process, increasing efficiency and quality, and creating additional values for the customers. On the other hand, Lean also has a disadvantage, and that is the challenge of employees to accept changes.

\section{References}

[1] Gjeldum, N., Mladineo, M., Crnjac, M., Aljinovic, A. (2018) Application of the integrative procedure for management of production and service improvement process on the assembly line, Proceedings of the 29th DAAAM International Symposium, pp.0031-0040, B. Katalinic (Ed.), Published by DAAAM International, , ISSN 17269679, ISBN 978-3-902734-20-4, Vienna, Austria, DOI: 10.2507/29th.daaam.proceedings.005 
[2] Duraković B., Bašić, H. (2013) Continuous Quality Improvement in Textile Processing by Statistical Process Control Tools: A Case Study of Medium-Sized Company Periodicals of engineering and natural sciences, ISSN 2303-4521, Vol. 1 No. 1, 39-46, DOI: 10.21533/pen.v1i1.15

[3] Jasarevic, S., Brdarevic, S., Imamovic, M., Diering, M. (2015) Standpoint of the top management about the effects of introduced quality system and continuation of activities of its improvement, International Journal for Quality Research, 9(2) 209-230, ISSN 1800-6450

[4] Januska M.; Faifr A. (2017) Optimization of the in-process control process using six sigma methods and tools, Proceedings of the 28th DAAAM International Symposium, pp.0280-0288, B. Katalinic (Ed.), Published by DAAAM International, ISSN 1726-9679, ISBN 978-3-902734-11-2, Vienna, Austria, DOI: 10.2507/28th.daaam.proceedings.038

[5] Bašić H., Duraković B., Softić, A. (2012) Six Sigma Model Testing in Optimizing Medium-Sized Company Production Process, Journal of Trends in the Development of Machinery and Associated Technology, Vol. 16, No. 1, p.p. 103-106, ISSN 2303-4009

[6] Durakovic, B., Demir, R., Abat, K., Emek, C. (2018) Lean Manufacturing: Trends and Implementation Issues, Periodicals of Engineering and Natural Sciences, Vol.6, No.1, pp. 130-143, ISSN 2303-4521

[7] Holweg, M. (2007) The genealogy of lean production, Journal of Operations Management, vol. 25, pp. 420 - 437

[8] Abdulmalek, F.A., Rajgopal, J. (2007) Analyzing the benefits of lean manufacturing and value stream mapping via simulation: A process sector case study, Int. J. Production Economics, vol. 107, p. 223- 236, 2007

[9] Bashkite, V., Karaulova. T. (2012) Intergration of green thinking into Lean fundamentals by theory of inventive problem-solving tools, Proceedings of the 23rd International DAAAM Symposium, Volume 23, No.1, ISSN 23041382, ISBN 978-3-901509-91-9, CDROM version, Ed. B. Katalinic, Published by DAAAM International, Vienna, Austria,

[10] Ohno, T. (1988) Toyota Production System Beyond Large-Scale Production, CRC Press, ISBN 0-915299-14-3, Boca Raton (USA)

[11] Duraković B., Bašić H. (2012) Textile cutting process optimization model based on six sigma methodology in a medium-sized company, Journal of Trends in the Development of Machinery and Associated Technology, Vol. 16, No. 1, p.p. 107-110, ISSN 2303-4009

[12] Company`s documentation and reports

[13] Gaskin, S. P., Griffin, A., Hauser, R. S., Katz, M. G., Klein, I. R. (2011) The Voice of the Customer, available from: https://www.mit.edu/ hauser/Papers/Gaskin_Griffin_Hauser_et_al\%20VOC\%20Encyclopedia\%202011.pdf

[14] Klaric, S. (2005), Quality management, `Dzemal Bijedic` University, ISBN 9958-9470-4-8, Mostar

[15] Mittal, K. K., Rao, P. S., Lean phisolophy (2016) Implementation in automobile company, Chapter 25 in DAAAM International Scientific Book 2016, pp.277-286, B. Katalinic (Ed.), Published by DAAAM International, ISSN 17269687, ISBN 978-3-902734-09-9, Vienna, Austria, DOI:10.2507/daaam.scibook.2016.25

[16] Pascal, D. (2015), Lean Production Simplified, CRC Press, ISBN 978-1-4987-0887-6, Boca Raton (USA)

[17] Bozickovic, R., Maric, B. (2013) Lean concept - a challenge to managers for better future of the company, Chapter 27 in DAAAM International Scientific Book 2013, pp. 491-510, B. Katalinic \& Z. Tekic (Eds.), Published by DAAAM International, ISBN 978-3- 901509-94-0, ISSN 1726-9687, Vienna, Austria, DOI: 10.2507/daaam.scibook.2013.27 